\title{
A procedure for localisation and electrophysiological characterisation of ion channels heterologously expressed in a plant context
}

\author{
E Hosy ${ }^{\dagger 1,2}$, G Duby ${ }^{\dagger 1,3}$, A-A Véry ${ }^{1}$, A Costa ${ }^{1,4}$, H Sentenac $^{1}$ and J-B Thibaud*1
}

Address: ${ }^{1 B}$ Biochimie et Physiologie Moléculaires des Plantes, UMR 5004, Agro-M/CNRS/INRA/UM2, F-34060 Montpellier Cedex 1, France, 2Present address: Laboratoire de Biophysique Moléculaire et Cellulaire, UMR 5090, CEA-DRDC-BMC, 17 rue des Martyrs, F-38054 Grenoble Cedex 9, France, ${ }^{3}$ Present address: Unité de Biochimie Physiologique, Institut des Sciences de la Vie, Université Catholique Louvain, Place Croix du Sud, 5-15, 1348 Louvain-la-Neuve, Belgium and 4 Present address: Division of Biology, Cell and Developmental Biology Section, and Center for Molecular Genetics, University of California San Diego, CA 92093-0116 La Jolla, USA

Email: E Hosy - ehosy@cea.fr; G Duby - duby@fysa.ucl.ac.be; A-A Véry - very@ensam.inra.fr; A Costa - acosta@ucsd.edu; H Sentenac - sentenac@ensam.inra.fr; J-B Thibaud* - thibaud@ensam.inra.fr

* Corresponding author †Equal contributors

Published: 19 December 2005

Plant Methods 2005, I:14 doi:10.1 186/1746-48|I-I-14

This article is available from: http://www.plantmethods.com/content/l/I//4

(C) 2005 Hosy et al; licensee BioMed Central Ltd.

This is an Open Access article distributed under the terms of the Creative Commons Attribution License (http://creativecommons.org/licenses/by/2.0), which permits unrestricted use, distribution, and reproduction in any medium, provided the original work is properly cited.

\begin{abstract}
Background: In silico analyses based on sequence similarities with animal channels have identified a large number of plant genes likely to encode ion channels. The attempts made to characterise such putative plant channels at the functional level have most often relied on electrophysiological analyses in classical expression systems, such as Xenopus oocytes or mammalian cells. In a number of cases, these expression systems have failed so far to provide functional data and one can speculate that using a plant expression system instead of an animal one might provide a more efficient way towards functional characterisation of plant channels, and a more realistic context to investigate regulation of plant channels.

Results: With the aim of developing a plant expression system readily amenable to electrophysiological analyses, we optimised experimental conditions for preparation and transformation of tobacco mesophyll protoplasts and engineered expression plasmids, that were designed to allow subcellular localisation and functional characterisation of ion channels eventually in presence of their putative (possibly over-expressed) regulatory partners. Two inward $\mathrm{K}^{+}$ channels from the Shaker family were functionally expressed in this system: not only the compliant KATI but also the recalcitrant AKTI channel, which remains electrically silent when expressed in Xenopus oocytes or in mammalian cells.

Conclusion: The level of endogenous currents in control protoplasts seems compatible with the use of the described experimental procedures for the characterisation of plant ion channels, by studying for instance their subcellular localisation, functional properties, structure-function relationships, interacting partners and regulation, very likely in a more realistic context than the classically used animal systems.
\end{abstract}




\section{Background}

Ion channel activity is essential to living cells in both plants and animals. Classical (or "forward") electrophysiology consists in measuring the cell membrane conductance and in deciphering this complex parameter towards the identification of the underlying ion transport systems and subsequently in getting as much information as possible on their functional properties, pharmacology, regulation and integration in cellular functions. In the late 70's to early 80 's, the invention of the patch-clamp technique allowed this to be performed down to the molecular "single channel" level. At about the same time, came another breakthrough: the cloning of genes encoding ion pumps and channels enabled the inception of what could be named "reverse" electrophysiology, i.e., taking a road that leads from the ex-situ characterisation of a given ion transport system to its function in the cell or organism. Since the early characterisation of an acetylcholine receptor and a $\mathrm{Na}^{+}$channel of electric fish $[1,2]$, this route has increasingly been taken while the knowledge of genomes became available.

In plants, ion channels are acknowledged to play crucial roles in transport of nutrient ions and control of membrane potential, and to be players or final targets of signal transduction pathways [3]. In planta, electrophysiological analyses have revealed a wide array of ion channels, differing in their ionic selectivity (anion or cation channels, selective cation channels permeable to either $\mathrm{K}^{+}$or $\mathrm{Ca}^{2+}$, poorly selective channels, etc.), or in their activation mechanism (voltage-gated, stretch-activated, or ligandgated channels). To date however, the molecular structures mediating many ionic currents described in vivo remain to be identified. Only a few plant channels, most of them belonging to the Shaker family [4], have been characterised at the molecular level and correlated with physiological functions. Little is known at the molecular level about non-selective cation channels, $\mathrm{Ca}^{2+}$ channels, stretch-activated channels or anion channels.

A convenient and realistic heterologous expression system is a prerequisite for successful "reverse" electrophysiology investigations. An ideal system should consist in cells devoid of endogenous ion transport activity ("electrically silent") and widely permissive in terms of foreign gene expression. The most widely used systems, Xenopus oocytes [5] or cell lines such as COS, Sf9 or HEK cells [610] do not fulfil this key requirement, but they generally offer acceptable compromises. Plant electrophysiologists have however experienced that strategies relying on heterologous expression in animal contexts are often poorly efficient for characterisation of plant ion channels. For example, this has been true for some Shaker-like $\mathrm{K}^{+}$channels [11], cation channels from the putative cyclic nucleotide gated channel (CNGC) family [12], glutamate receptors [13,14] and anion channels (CLCs) [15]. Such difficulties might be due to problems in RNA translatability and protein targeting, or to differences in post-translational modifying processes or in control by interacting protein partners, between the plant native context and the animal heterologous one. Surprisingly, in some cases, after several failures to characterise a given plant channel in different animal expression systems, the use of another animal system can open the way to functional analyses. This has been the case for the Arabidopsis Shaker $\mathrm{K}^{+}$channel AKT1, which is electrically silent when expressed in Xenopus oocytes [11] but gives rise to hyperpolarisation activated inward currents when expressed in insect cells [16]. However, the search for the suitable system will remain quite empirical until the reasons why a given channel is expressed in a functional state or not in a given animal system are discovered.

Bei and Luan opened the way towards a "green" heterologous expression system when they found that tobacco mesophyll protoplasts are devoid of $\mathrm{K}^{+}$inward currents and demonstrated that the KAT1 Shaker channel could be heterologoulsy expressed and subsequently characterised therein [17]. The stable transformation protocol by Agrobacterium infiltration of leaf disks and subsequent regeneration of a plant [18], however, is time consuming. Another drawback of this method is that ubiquitous expression of some transgenes may, in some instances, prevent the regeneration of a transformed plant that is required to obtain mesophyll protoplasts, or induce inopportune transcriptome modifications. On the other hand, the transient expression of protein-GFP fusions in tobacco cells has been used since about 8 years to study the targeting of proteins $[19,20]$ suggesting possible use of these cells for electrophysiological characterisation of electrogenic transport systems [21]. Based on this, we developed a new procedure relying on transient transformation of tobacco mesophyll protoplasts. Vectors (available upon request) were engineered that allow selection of the transformed protoplasts (GFP reporter), expression of GFPtagged or untagged proteins (for subcellular localisation and electrophysiological analyses, respectively), and coexpression of two different proteins in order to investigate their functional interactions. A PEG-mediated transformation protocol was adapted and the potential usefulness of the method was assessed by functional expression of the AKT1 channel, a result that had not been obtained in Xenopus oocytes or COS cells as mentioned above. The whole set of data indicates that the method can indeed provide a new way to functional analyses of plant ion channels. 
(A) pLoc Localisation plasmid

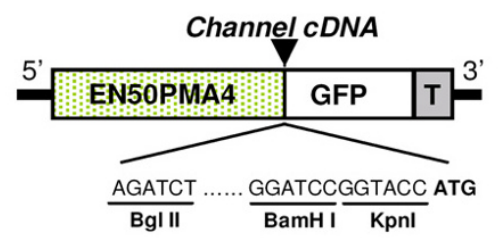

(B) pFunct+Tag Functional expression+cell tagging plasmid

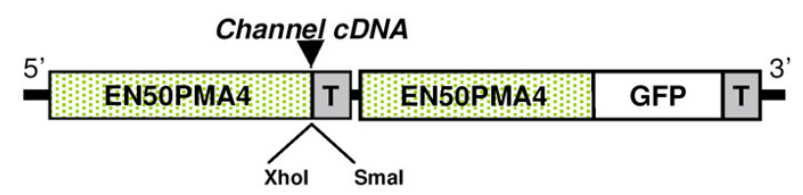

(C)

pFunct Functional expression plasmid

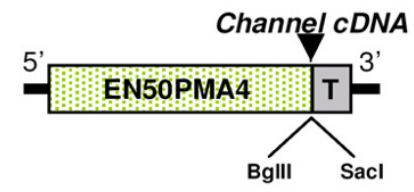

Figure I

Expression vectors engineered for transformation of tobacco mesophyll protoplasts. (A) pLoc. This vector carries a single over-expression cassette. The green fluorescent protein cDNA ("GFP") is framed by a strong promoter ("EN50PMA4") and a terminator ("T"). Three restriction sites (Bgl II, BamH I, Kpn I) are available for in-phase cloning of another cDNA. "ATG" indicates the first GFP codon. This vector allows the expression of fusion polypeptides with a GFP-tag in C-terminal for localisation purpose. (B)

pFunct+Tag. This vector carries two expression cassettes both featuring the EN50PMA4 promoter and the T terminator. The first cassette encodes the GFP alone and the second one displays two restriction sites (Xho I, Sma I) for cDNA cloning. pFunct+Tag is used for functional expression of the recombinant cDNA while fluotagging transformed cells. (C) pFunct. This vector has the same construction as pFunct+Tag but the GFP cassette is absent. It is used, in combination of pLoc or pFunct+Tag, when two cDNAs are to be coexpressed (see text). EN50PMA4 is a tobacco enhanced promoter (see "Methods"); and T: is the nopaline synthase terminator of Agrobacterium tumefaciens. These vectors were obtained in a PTZ-19U plasmid (Stratagene, LaJolla, CA, USA) background.

\section{Results}

Genetic constructions for transient expression in tobacco protoplasts

Expression plasmids were engineered to display the following key features: (i) tagging of transformed cells, (ii) obtaining high expression levels of the studied protein(s), (iii) allowing both subcellular localisation and functional characterisation of the protein(s) of interest.
Selection markers such as antibiotic resistance or GUS staining are not suited to selection of protoplasts intended for patch-clamping. We therefore opted for a GFP-based selection. Indeed, GFP is easily expressed in plant cells with few or no drawbacks, when not fused to another protein. Fusion of GFP to membrane proteins, $\mathrm{K}^{+}$channels in our case, can be a solution for both detecting transformed cells and studying tagged-polypeptides [21]. It cannot be excluded, however, that, in some instances, tag-fused polypeptides display altered function and/or impaired multimeric assembly or interaction with regulating factors [22]. Therefore, vectors were constructed to enable either expression of the protein of interest fused to GFP for subcellular localisation, or co-expression of this protein and of GFP for functional characterisation purposes, as detailed below.

Four plasmids containing one or two expression cassettes were constructed. Each expression cassette was featured with the EN50PMA promoter and the nopaline synthase terminator of Agrobacterium tumefaciens (noted $T$ in Figure 1), a combination previously used for transient expression of mitochondria-targeted GFP in tobacco protoplasts [23]. The EN50PMA promoter consists of the pma4 (plasma membrane $\mathrm{H}^{+}$- ATPase isoform \# $\underline{4}$ gene) promoter in which the CaMV $35 \mathrm{~S}$ enhancer is inserted at position -50 upstream from the transcription start of the pma4 gene. This promoter has been shown to yield expression levels at least ten fold higher than the classical CaMV 35 s promoter [24].

In the first plasmid, called $p L o c$, a short polylinker (made of three restriction sites) was inserted between EN50PMA and the GFP-coding sequence (Figure 1A). This plasmid, expressing a GFP-tagged polypeptide with the polypeptide cDNA (free from STOP codon) cloned at the polylinker in frame with GFP, was used for subcellular localisation.

The second plasmid, called pFunct+Tag contained two expression cassettes, separately expressing the cloned polypeptide cDNA and GFP (Figure 1B). It was used for both functional expression of the polypeptide and fluotagging of transformed protoplasts.

The third plasmid, called pFunct, contained one single expression cassette allowing expression of the cloned polypeptide without a GFP-tag (Figure 1C). It can be used in co-transformation experiments. In such experiments, this vector, recombining one cDNA, can be co-expressed with either the $p L o c$ or $p$ Funct+Tag plasmids, recombining another cDNA, thereby allowing the study of interactions between the two encoded polypeptides, regarding their subcellular localisation or functional properties, respectively. 
In control experiments, empty pLoc vector was used to express GFP alone. This was made for electrophysiological analysis of control protoplasts having undergone the transformation process without expression of a foreign cDNA (except GFP).

\section{Preparation and transformation of tobacco protoplasts} Tobacco leaf protoplasts have been obtained and subsequently transformed for GFP-enabled localisation purposes since about a decade $[25,26]$. We experienced, however, that obtaining protoplasts readily amenable to patch-clamp experiments required the digestion, purification and transformation steps to be optimised as described below (see the proposed protocol in "Methods"). The duration of digestion appeared to be critical for the success of patch-clamp experiments. Despite the fact that a high transformation efficiency was obtained on 15hour digested cells, a 19-hour digestion time resulted in an increased gigaseal success rate, probably because of an improved accessibility of the patch pipette to the cell membrane. A high density solution (MLO6) was added to the final incubation medium (see "Methods") in order to increase the solution density and to separate, after a 7 minute-centrifugation at $110 \mathrm{~g}$, the alive and floating protoplasts from the sedimented dead ones. Performing the digestion and the transformation in the dark and subsequently keeping the protoplasts in the dark at $19^{\circ} \mathrm{C}$ until patch-clamping, also facilitated gigaseals probably because darkness and moderate temperature slowed new cell wall synthesis.

The transformation was performed with a PEG-mediated technique. Several polymers of PEG were tested at different concentrations and the best yield of transformation (averaging 20\%) was obtained with a 25\% (w/v) concentration of PEG-6000. The electroporation transformation technique was also tested but a lot of cells did not withstand the electrical pulse and the yield of transformation was around 5\%. Moreover, this technique requires a lot of DNA $(30 \mu \mathrm{g})$ and cells (1.5 $10^{6}$ cells/transformation) [27] whereas, in our conditions, the PEG technique requires 5 $\mu \mathrm{g}$ DNA and around $5.10^{5}$ cells only per transformation [28]. A critical step for transformation is purity of the DNA. In our experiments, Nucleobond ${ }^{\circledR}$ AX affinity columns (Macherey-Nagel, Düren, Germany) were used for DNA purification and a drastic decrease in the efficiency of transformation was observed when old DNA preparations (> 1 month) or DNAs prepared by cell lysis and ethanol precipitation were used.

\section{Tobacco mesophyll protoplasts show weak inward $\mathrm{K}^{+}$and Cl-currents}

The native plasma membrane conductance of tobacco mesophyll protoplasts was investigated to test whether they could be used as hosts to express $\mathrm{K}^{+}$(or cationic) or/ and $\mathrm{Cl}^{-}$(anionic) channels. The patch-clamp technique was applied to non-transformed and to GFP-tagged (transformed with empty $p L o c$ vector) protoplasts. In both cases, similar recordings were obtained revealing that the native membrane conductance was modified neither by the PEG treatment nor by expression of GFP, and that the PEG treatment did not alter the membrane amenability to patch-clamping (not shown).

Two patterns of native inwardly-rectifying $\mathrm{K}^{+}$currents could be observed during hyperpolarising pulses. About one third of the cells displayed virtually no inward current (Figure 2C). The other cells displayed low intensity $(9 \pm 3$ pA. $\mu \mathrm{m}^{-2}(\mathrm{n}=9)$ at $\left.-200 \mathrm{mV}\right)$ currents, which activated instantaneously upon hyperpolarisation below $-140 \mathrm{mV}$ (Figure 2B), and which were insensitive to $\mathrm{Cs}^{+}$, a classical $\mathrm{K}^{+}$channel blocker (not shown).

Large $\left(45 \pm 13\right.$ pA. $\mu \mathrm{m}^{-2}(\mathrm{n}=10)$ at $\left.+100 \mathrm{mV}\right)$ outwardlyrectifying $\mathrm{K}^{+}$currents were activated by depolarising pulses (Figure 2C). These currents were probably due to the activity of Shaker channels as they displayed activation kinetics and extracellular potassium dependence reminiscent of those described for SKOR and GORK Arabidopsis outwardly-rectifying Shaker channels [29-31].

An average current-voltage relationship of control protoplasts (transformed with empty pLoc vector) is shown in Figure 2D. The low intensity of the instantaneous inward $\mathrm{K}^{+}$current seems compatible with the use of tobacco mesophyll protoplast as an expression system for heterologous inward $\mathrm{K}^{+}$channels.

Native anionic currents in these mesophyll protoplasts were recorded when $\mathrm{Cl}^{-}$ions were the sole diffusible anions in both bath and pipette solutions $\left(\mathrm{Cs}^{+}\right.$being added to block the $\mathrm{K}^{+}$currents). Outward currents were recorded $\left(30 \pm 9.6\right.$ pA. $\mu \mathrm{m}^{-2}(\mathrm{n}=10)$ at $+100 \mathrm{mV}$, Figure $\left.2 \mathrm{E}-\mathrm{F}\right)$, indicating that depolarisation-activated anion channels dominated the anionic conductance.

In summary, due to their moderate native conductances, tobacco mesophyll protoplasts seemed usable for characterisation of heterologously expressed $\mathrm{K}^{+}$(cation)- or $\mathrm{Cl}^{-}$ (anion)-selective channels, preferably those channels mediating inward currents and possibly those mediating outward currents, provided that high heterologous expression level can be achieved.

\section{Functional expression and localisation of two inward $\mathrm{K}^{+}$ channels}

In the following, the use of tobacco protoplasts for transient expression of functional channels was evaluated with two model inwardly-rectifying Shaker channels cloned from Arabidopsis: AKT1 [32] and KAT1[33]. 

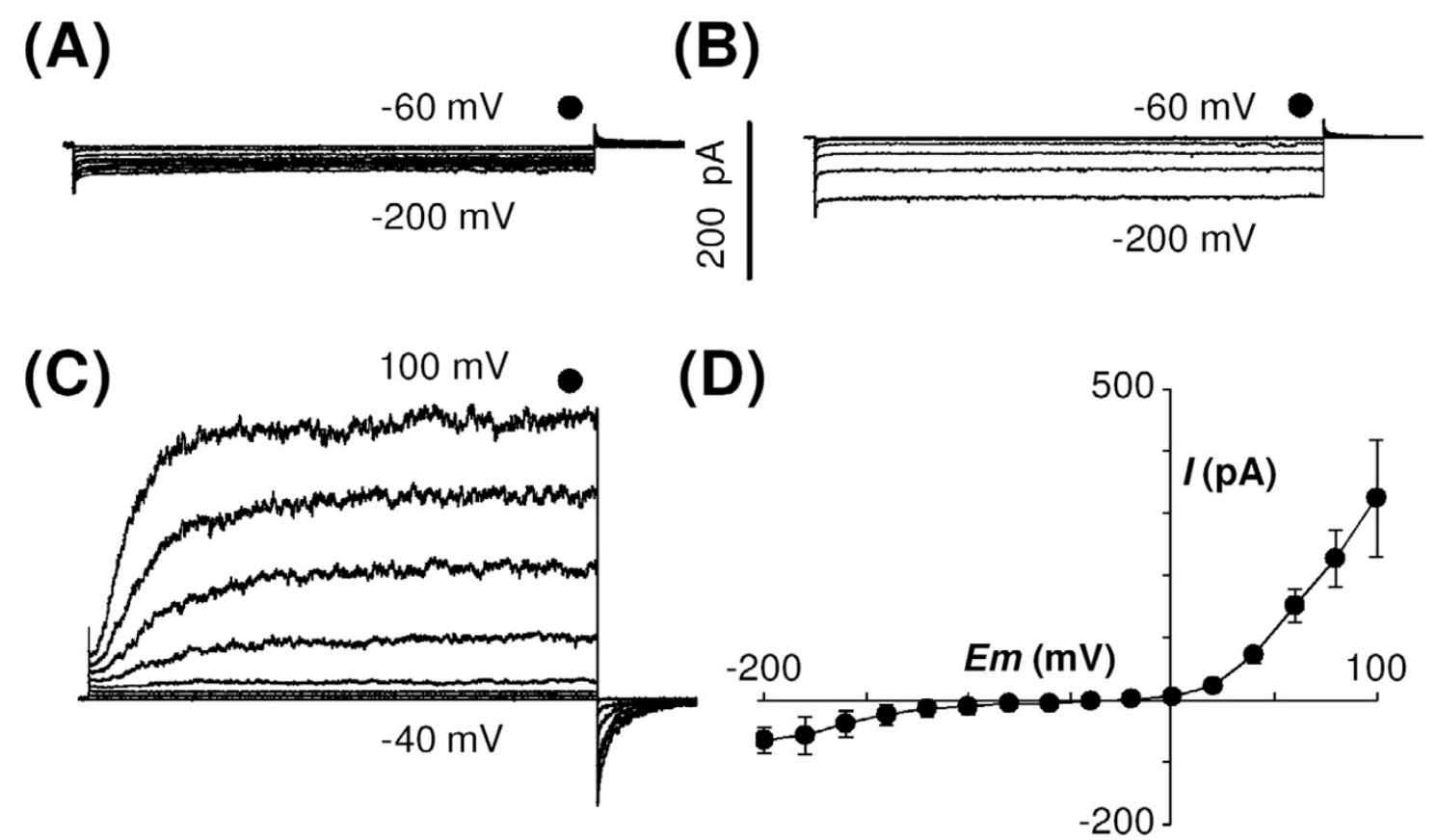

\section{(E)}

(F)

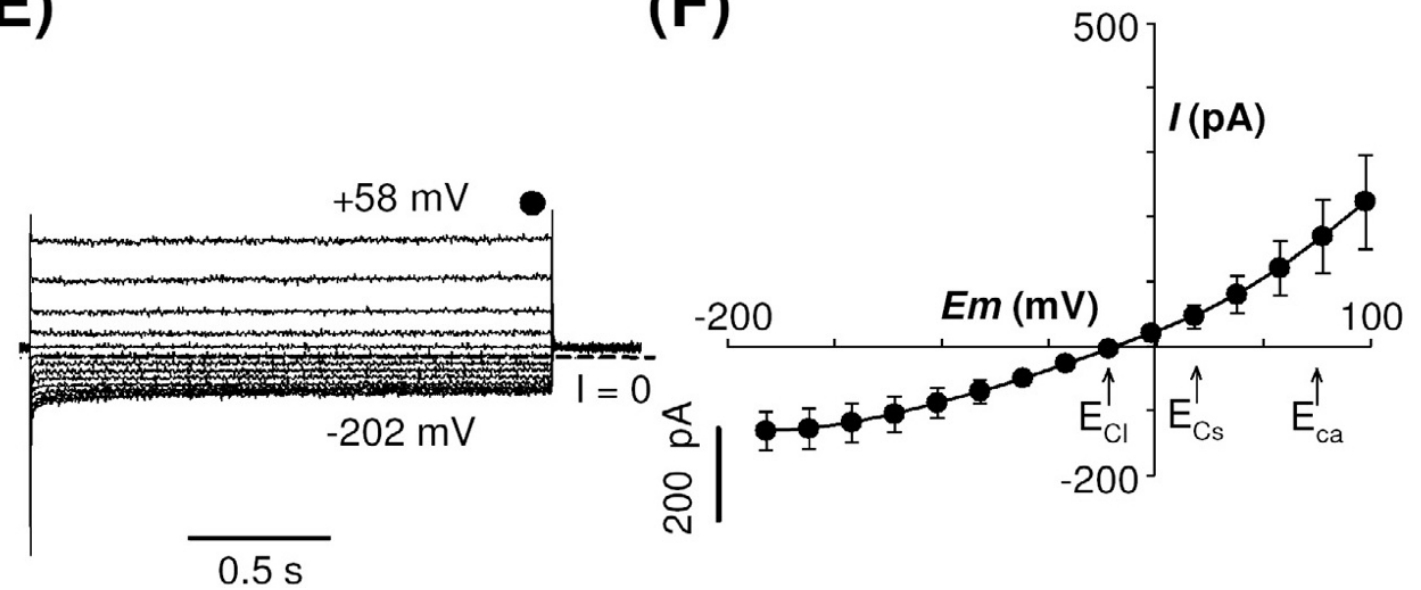

Figure 2

Native $\mathrm{K}^{+}$and $\mathrm{Cl}$ - currents in tobacco mesophyll protoplasts transformed by the empty pLoc vector. (A, B) Typical recordings illustrating the two patterns of whole-cell inward $\mathrm{K}^{+}$currents elicited by membrane hyperpolarisation. $35 \%$ of the patch-clamped protoplasts displayed the "no-current" pattern shown in (A). $65 \%$ of the patch-clamped protoplasts displayed the voltage-dependent instantaneous weak current pattern shown in (B). (C) Typical recordings of whole-cell outward $\mathrm{K}^{+}$currents elicited by membrane depolarisation on the same protoplasts as in $(\mathrm{A})$ and $(\mathrm{B})$. The voltage steps ranged from -60 $\mathrm{mV}$ to $-200 \mathrm{mV}(\mathrm{A}, \mathrm{B})$ and from $-40 \mathrm{mV}$ to $+100 \mathrm{mV}(\mathrm{C})$ in $+20 \mathrm{mV}$ increments, from a holding potential of $-40 \mathrm{mV}$. The symbol above the records in a-c indicates the time of "steady-state" current sampling. (D) Average (mean $\pm S E, n=10$ ) of native steady-state $\mathrm{K}^{+}$currents in tobacco mesophyll protoplasts plotted against membrane potential. (E) Typical recordings of native whole-cell $\mathrm{Cl}^{-}$currents recorded in protoplasts exposed to $\mathrm{CsCl}$ in pipette and extracellular solutions (see "Methods"). The voltage steps ranged from $-202 \mathrm{mV}$ to $+58 \mathrm{mV}$ in $+20 \mathrm{mV}$ increments and the holding potential was $-22 \mathrm{mV}$. Dashed line marks zero current level. The symbol above the records indicates the time of "steady-state" current sampling. (F) Average (mean \pm $\mathrm{SE}, \mathrm{n}=10$ ) of native steady-state $\mathrm{Cl}$-currents in tobacco mesophyll protoplasts plotted against membrane potential. Voltage dependence, at steady state, of the native chloride currents in tobacco mesophyll protoplasts (means $\pm S E ; n=10$ ). $E_{C l}, E_{C_{S}}$ and $\mathrm{E}_{\mathrm{Ca}}$ represent equilibrium potentials for $\mathrm{Cl}_{-}, \mathrm{Cs}^{+}$and $\mathrm{Ca}^{2+}$ respectively (see detailed content of bath and pipette solutions in "Methods"). 
(A)

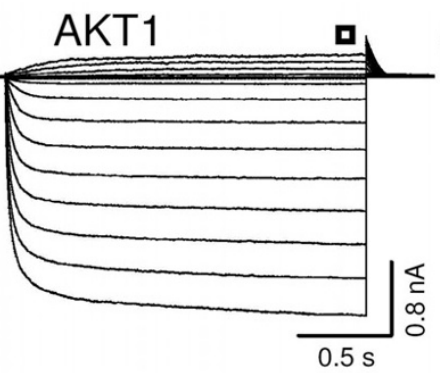

(C)

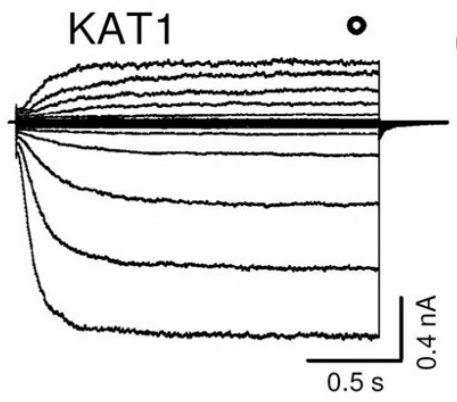

(B)

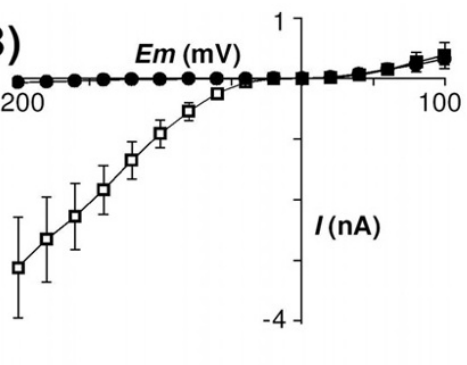

(D)
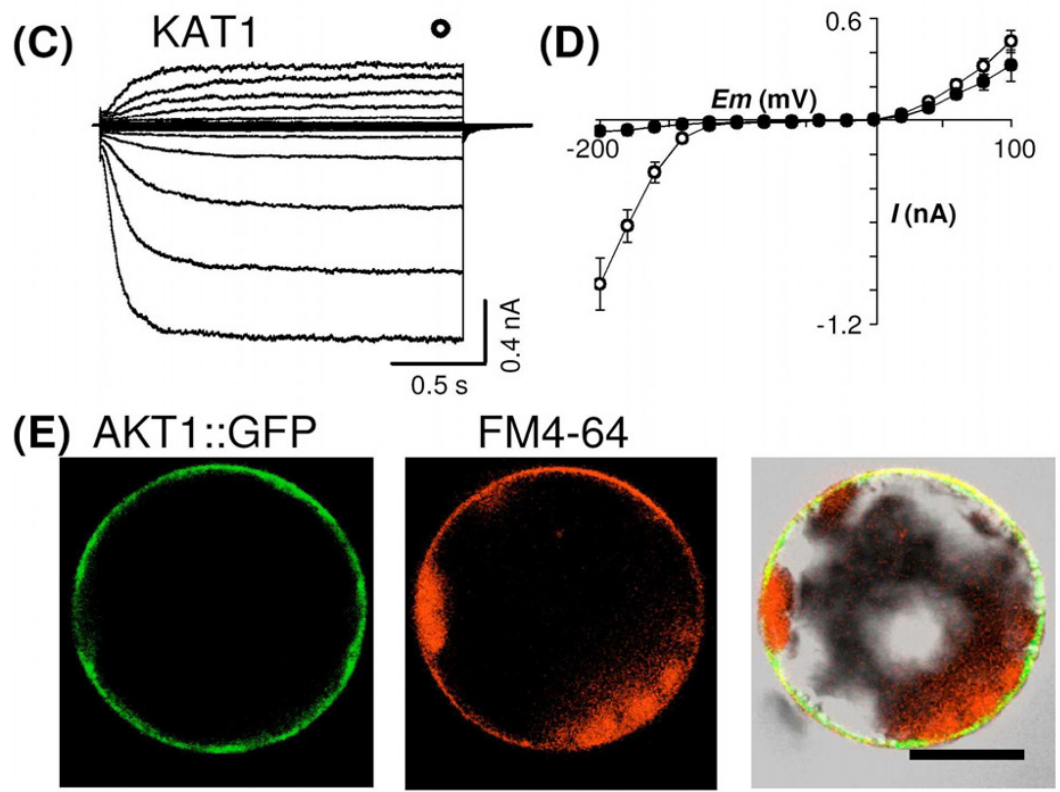

(F)
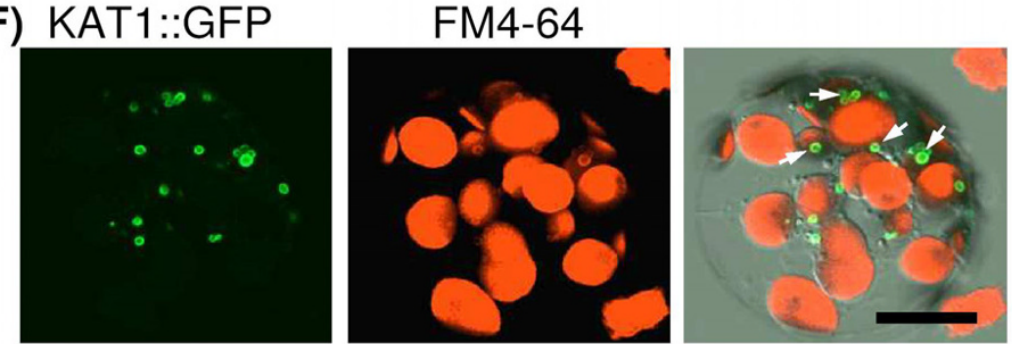

Figure 3

Functional expression and subcellular localisation of AKTI and KATI channels in tobacco mesophyll protoplasts. (A) and (C) Typical recordings of the whole-cell inward and outward $\mathrm{K}^{+}$currents in patch-clamped tobacco mesophyll protoplasts respectively transformed with $A K T I$-carrying and $K A T I$-carrying pFunct+Tag vectors. The voltage steps ranged from $-200 \mathrm{mV}$ to $+100 \mathrm{mV}$ in $20 \mathrm{mV}$ increments. The holding potential was $0 \mathrm{mV}$ and $-40 \mathrm{mV}$ respectively for AKTI and KATI expressing protoplasts. The symbol above the records in a and $\mathrm{c}$ indicates the time of "steady-state" current sampling. (B) and (D) Current-voltage relationships at steady state in control tobacco mesophyll protoplasts (closed circles in both B and D) and in AKTI-expressing (open squares in B) and KATI-expressing (open circles in d) ones (means $\pm S E ; n=I 6$ for AKTI, $n=I 3$ for KATI). (E, F) Confocal microscopy sections of protoplasts transformed with AKTI-carrying (E) and KATI-carrying (F) pLoc vectors. The left panels display protoplast sections analysed for the GFP fluorescence, the middle panels the same sections analysed for chloroplast auto-fluorescence and FM4-64 fluorescence and the right panels the overlay of the two former panels with the transmission light image from the same protoplast section. FM4-64 was $50 \mu M$ in both $(E)$ and $(F)$ and was incubated for $10 \mathrm{~min}$ on ice in (E) and for $40 \mathrm{~min}$ at room temperature in (F). Some places where GFP and FM4-64 fluorescence co-localises are marked by white arrows in $(F)$. Scale bar $=20 \mu \mathrm{m}$. 
AKT1 had to be tested as it has only been functionally expressed in Sf9 (insect) cells [16] and yeast cells [32,34], but neither in Xenopus oocytes nor in COS cells so that this channel has been much less studied than KAT1. In contrast, the activity of KAT1 has successfully been recorded in a large set of heterologous expression systems: Xenopus oocytes [35,36], COS cells [37], Sf9 cells [38], yeast cells [34,39], tobacco mesophyll protoplasts [17] and Vicia faba guard cell protoplasts [21]. This strikingly compliant plant Shaker subunit has therefore been the most extensively described one, becoming the model plant Shaker channel for structure-function analysis. It was here used as a positive control of the usability of the transiently transformed tobacco protoplasts.

When patch-clamped, the GFP-labelled protoplasts transformed with the pFunct+Tag-AKT1 vector displayed exogenous voltage-gated $\mathrm{K}^{+}$currents, activating below a $c a .-40$ $\mathrm{mV}$ voltage threshold, exhibiting time dependent activation and inward rectification (Figure 3A) and reversing at a membrane potential close to the equilibrium potential for $\mathrm{K}^{+}$ions (not shown). These currents were similar to those observed in Sf9 cells infected by AKT1-recombinant bacculoviruses [16] or to the native ones recorded in root hairs of atkc1-1 knock-out plants, which are likely to express homomeric AKT1 channels [40]. An average (mean $\pm \mathrm{SE}, \mathrm{n}=16$ ) steady-state current/voltage curve for control and AKT1-expressing protoplasts is shown (Figure $3 \mathrm{~B})$ to highlight the marked change in inward currents, the outward currents being unchanged.

Electrophysiological recordings on pFunct+Tag-KAT1transformed protoplasts revealed large exogenous inwardrectifying $\mathrm{K}^{+}$currents, which exhibited typical features of KAT1 currents [41], such as a time-dependent activation below a negative voltage threshold (here, $c a$. $-120 \mathrm{mV}$; Figs. $3 \mathrm{c}$ and $3 \mathrm{~d}$ ).

The values of the voltage-gating parameters (activation threshold potential and, when available, so-called "Boltzmann" parameters, i.e. half-activation potential and apparent gating charge) previously obtained either in native or in heterologous contexts for AKT1 and KAT1 channels are compared to the ones obtained for these channels in the present work (Table 1). It appears that the values of these parameters depend on the expression context but that the present ones obtained in tobacco are closer to those obtained in the native context (Arabidopsis) than those obtained in animal or yeast cells.

Protoplasts transformed with the pLoc-AKT1 vector displayed a green fluorescence distribution (Figure 3E, left photograph) suggesting targeting of the AKT1::GFP fusion protein to the cell plasma membrane. This was assessed by the green fluorescence co-localisation (Figure 3E, right photograph) with the red fluorescence of the membranemarker FM4-64 (10 min incubation, Figure 3E, middle photograph). This pattern contrasted with the one displayed by protoplasts expressing GFP alone (not shown here but see Figure 4A, below). The membrane localisation of the GFP fluorescence in pLoc-AKT1 transformed protoplasts was fairly stable.

The situation was quite different with pLoc-KAT1 transformed protoplasts: the KAT1-attached GFP fluorescence was found essentially localised to 1 to $4 \mu \mathrm{m}$ diameter structures (Figure 3F, left). These structures were assumed to be endocytic vesicles [42]. In order to check this hypothesis, the FM4-64 dye was incubated for $40 \mathrm{~min}$ with the protoplasts (Figure 3F, middle), a time allowing endocytic vesicles that appear upon vesicular internalisation of the plasma membrane to be labelled [43]. Many KAT1::GFP-labelled structures also displayed the red FM464 fluorescence (Figure 3F, right), suggesting that KAT1::GFP had undergone endocytosis. Similar intracellular GFP-labelled structures were already observed in KAT1::GFP-expressing Vicia guard cells and were also suggested to belong to the endocytic pathway [21].

\section{Co-expression of two polypeptides}

The possibility of obtaining co-expression of two distinct polypeptides located on two different plasmids, as reported previously [28], was also tested using the present experimental procedures. PEG-mediated transformation of tobacco mesophyll protoplasts was attempted with a mixture of an empty $p L o c$ vector and either $p F u n c t-A K T 1$ or pFunct-KAT1. After this step, those cells having integrated the latter vector were spotted by green fluorescence. When patch-clamped, all the GFP-tagged protoplasts (of 25 AKT1 co-transformed protoplasts or of 23 KAT1 co-transformed ones) displayed exogenous currents (of AKT1- and KAT1-type, respectively). This evidenced that both vectors present in the transformation mixture were expressed in $100 \%$ of the transformed protoplasts.

\section{Transformed protoplasts can be used for at least 24 hours in patch-clamp experiments}

To determine the best conditions for patch-clamp recordings in transformed tobacco protoplasts, the kinetics of green fluorescence apparition (reporting the expression of the exogenous proteins) and the kinetics of the wall reconstruction (limiting the access to the membrane for the pipette) were studied.

In a preliminary step, it was verified that every cell harbouring GFP expression that was patch-clamped displayed an exogenous conductance due to the activity of the studied channel (KAT1 and AKT1 channels being used as controls for functional expression of heterologous polypeptides). Green fluorescence (Figure 4A, left) was 
Table I: A comparison of the values of voltage-gating parameters of KATI and AKTI channels in different expression contexts (see text).

\begin{tabular}{|c|c|c|c|c|c|c|c|c|}
\hline \multicolumn{2}{|r|}{ Channel } & \multicolumn{6}{|c|}{ Mean value for voltage-gating parameters of the channel in } & \multirow[t]{3}{*}{ References } \\
\hline & & \multicolumn{3}{|c|}{ Animal cells } & \multirow[t]{2}{*}{ Yeast cells } & \multicolumn{2}{|c|}{ Plant cells } & \\
\hline & & $\begin{array}{l}\text { Xenopus } \\
\text { oocytes }\end{array}$ & $\begin{array}{l}\text { insect } \\
\text { cells }(S f 9)\end{array}$ & $\begin{array}{c}\text { Green } \\
\text { monkey cos } \\
\text { cells }\end{array}$ & & $\begin{array}{l}\text { Tobacco } \\
\text { mesophyll } \\
\text { cells }\end{array}$ & $\begin{array}{l}\text { Arabidopsis } \\
\text { native cells }\end{array}$ & \\
\hline \multirow[t]{3}{*}{ AKT I } & $\begin{array}{l}\text { Activation } \\
\text { potential } \\
(\mathrm{mV})\end{array}$ & No current $(1)$ & $-70 /-80(1)$ & No current ${ }^{(2)}$ & $-140(3)$ & -40 & $-40(4)$ & (I) Ref [16] \\
\hline & Gating charge & No current $(1)$ & $1.5(1)$ & No current ${ }^{(2)}$ & n.r. $(3)^{*}$ & $\begin{array}{c}1.3 \pm 0.2 \\
(n=5)\end{array}$ & n.r. (4),* & $\begin{array}{l}\text { (2) Erwan } \\
\text { Michard, } \\
\text { unpublished } \\
\text { (3) Ref. [34] }\end{array}$ \\
\hline & $\begin{array}{l}\text { Half- } \\
\text { activation } \\
\text { potential } \\
(\mathrm{mV})\end{array}$ & No current $(1)$ & $-123(1)$ & No current(2) & n.r. $(3), *$ & $\begin{array}{l}-95 \pm 10 \\
(n=5)\end{array}$ & n.r. (4).* & $\begin{array}{l}\text { (4) Ref. [40] } \\
\text { (5) Ref. [35] }\end{array}$ \\
\hline \multirow[t]{3}{*}{ KATI } & $\begin{array}{l}\text { Activation } \\
\text { potential } \\
(\mathrm{mV})\end{array}$ & $-80(5)$ & $-60 /-80(6)$ & $-100(7)$ & $-120(3)$ & -120 & $-120(8)$ & $\begin{array}{l}\text { (6) Ref. [38] } \\
\text { (7) Ref. [37] }\end{array}$ \\
\hline & Gating charge & $\begin{array}{l}1.7 \pm 0.2 \\
(n=5)^{(9)}\end{array}$ & n.r.(6).* & $1.6(7)$ & n.r..$^{(3)}{ }^{*}$ & $\begin{array}{c}1.7 \pm 0.1 \\
(n=4)\end{array}$ & $\begin{array}{l}1.6 \pm 0.2 \\
(n=5)^{(10)}\end{array}$ & $\begin{array}{l}\text { (8) Ref. [46] } \\
\text { (9) Ref. [36] }\end{array}$ \\
\hline & $\begin{array}{l}\text { Half- } \\
\text { activation } \\
\text { potential } \\
(\mathrm{mV})\end{array}$ & $\begin{array}{l}-138 \pm 7 \\
(n=5)^{(9)}\end{array}$ & n.r. ${ }^{(6), *}$ & $-135(7)$ & n.r. (3),* & $\begin{array}{c}-164 \pm 6 \\
(n=4)\end{array}$ & $\begin{array}{l}-157 \pm 7 \\
(n=5)^{(10)}\end{array}$ & $\begin{array}{l}\text { (10) Eric Hosy, } \\
\text { unpublished } \\
* \text { not } \\
\text { reported by } \\
\text { these authors }\end{array}$ \\
\hline
\end{tabular}

detectable as soon as 4 hours after the transformation step and the number of GFP-labelled cells subsequently reached a plateau by 55 hours following the transformation event (Figure 4B). Once this steady-state was reached, the yield of transformation could be estimated: it averaged $20 \%$. Interestingly, with respect to this final ratio of GFP-tagged cells, the time-course of the proportion of cells showing green fluorescence was fairly reproducible and poorly dependent on whether a channel was coexpressed or on which construct was used for this coexpression (Figure 4B). Operationally, one GFP-tagged cell amongst fifteen is an acceptable threshold for attempting patch-clamping on a cell culture dish. Hence, with a transformation efficiency of $20 \%$, the number of GFP-tagged cells on a dish was large enough to attempt patch-clamp recordings about 12 hours after the transformation process (Figure 4B).

In a second set of experiments, detection of cell wall regeneration by transformed protoplasts was monitored (Figure 4A, middle and right), using the calcofluor dye (Fluorescent brightener 28; Sigma). Except for the ca. 15 $\%$ of mis-digested protoplasts, which were stained immediately after the transformation, the first neo-synthesised cell wall pieces could be detected by 20 hours after the transformation (Figure 4C). Expression of GFP or both GFP and channel did not merely change the wall synthesis kinetics (Figure 4C). Sixty to $70 \%$ of the protoplasts had synthesised (pieces of) a new wall by 40-45 hours after the transformation (Figure 4C), so that it became subsequently difficult to get good access to the membrane with the patch pipette.

These observations mean that the patch-clamp recordings can begin 12 hours after the transformation (expression time) and the currents can be measured up to 40 hours after the transformation. The time window for protoplasts usability is therefore at least 24 hours wide (Figure 4D). Interestingly, current intensity at $-200 \mathrm{mV}$ (here related to channel expression level) did not markedly increase with time after transformation (Figure 4E) and the expression level of channels in the membrane was high enough to record macroscopic currents as soon as GFP fluorescence was detectable.

In an attempt to extend the time allowed for patch-clamping, the newly synthesised cell wall was exposed to the previously used digest solution or to a solution enriched in enzymes. After 1, 2 or 5 hours of digestion, however, the quality of cell membrane obtained did not allow 
(A)
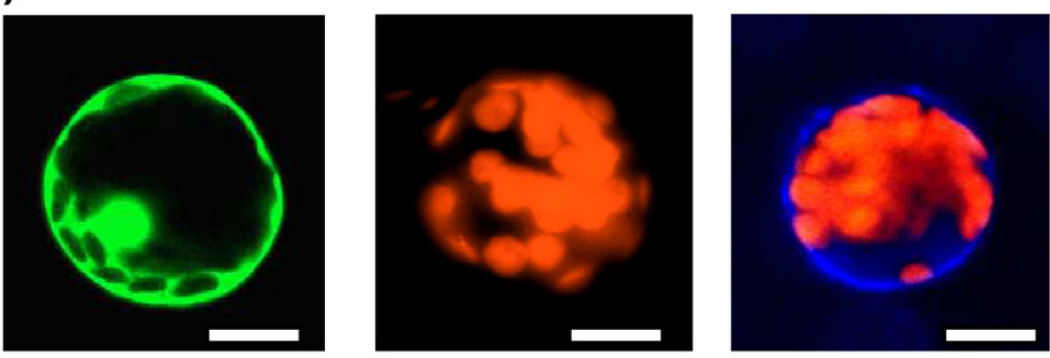

(B)

(C)
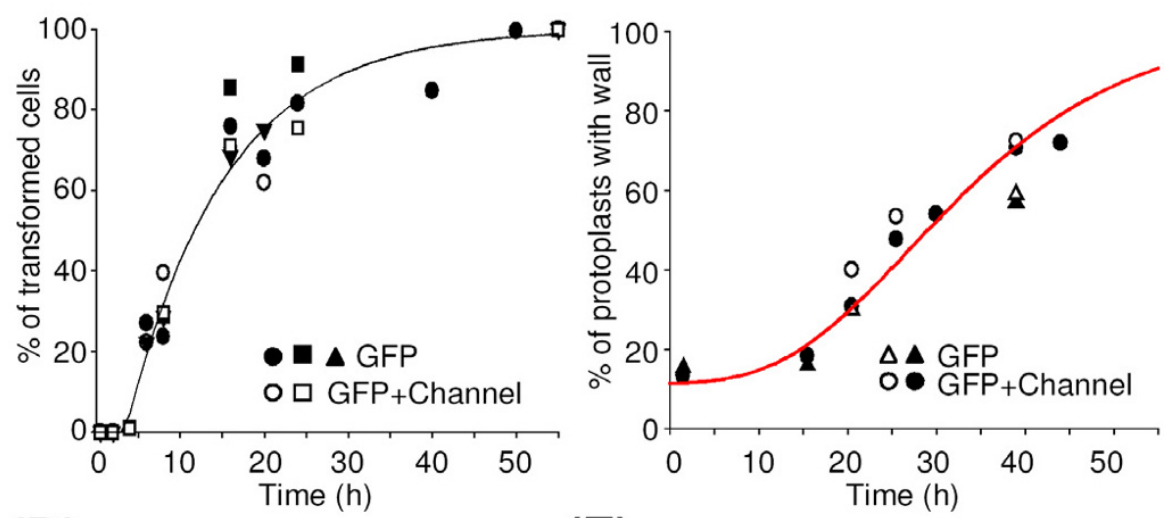

(D)

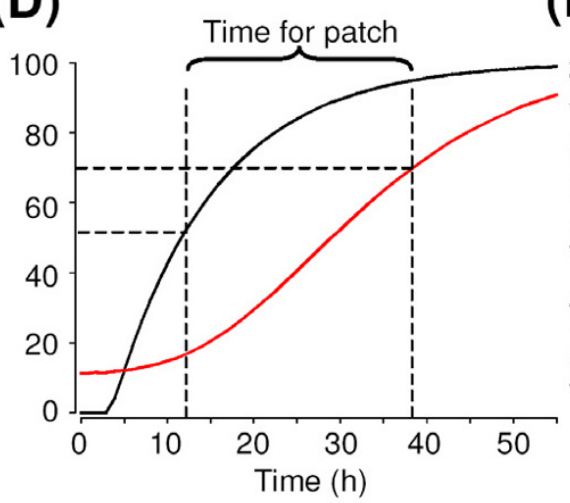

(E)

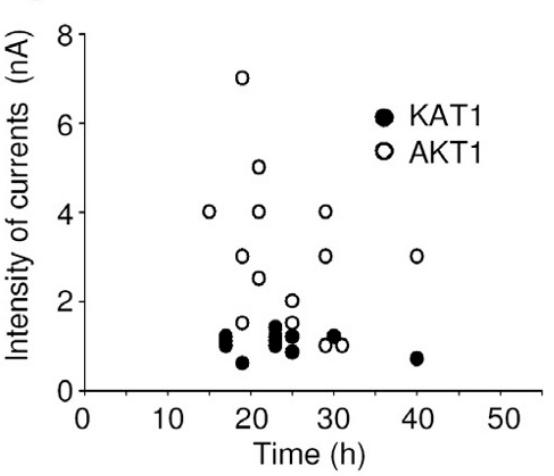

Figure 4

Windowing the time allowed for patch-clamp recordings. (A) Confocal microscopy sections of tobacco mesophyll protoplasts transformed with empty "localisation" plasmids (control protoplasts). Left panel: protoplast analysed for GFP detection. Middle and right panels: images of protoplasts bathing in calcofluor dye solution respectively without and with wall. Bar $=20 \mu \mathrm{m}$. (B) Time-course of GFP expression in transformed tobacco mesophyll protoplasts. The number of cells displaying GFP expression at a given time after transformation is expressed as a percentage of the number of cells which finally ( 55 hours after transformation) expressed GFP. Closed symbols: 3 independent transformations with empty pLoc ("GFP"). Open symbols: 2 independent transformations with pFunct+Tag-KATI ("channel+GFP"). About 500 transformed cells were considered for each experiment. Line represents exponential fit of the data. (C) Time-course of cell wall regeneration. The cell wall was marked with calcofluor dye. A cell was considered to have a wall if part of its surface showed blue staining. Each point represents about 200 protoplasts. Triangles and circles represent protoplasts transformed respectively with empty pLoc and pFunct+Tag-KATI. Dark symbols represent all the protoplasts and open symbols those displaying green fluorescence. Line represents sigmoidal fit of the data. (D) Operational time window for patch-clamp recordings. Superimposition of the GFP apparition and cell wall synthesis fitted curves allows determination of a time frame for patch-clamp experiments (see text). (E) Timecourse of the amplitude of steady-state currents recorded at $-200 \mathrm{mV}$ in tobacco mesophyll protoplasts transformed with pFunct+Tag-KATI (dark symbols) or pFunct+Tag-AKTI (open symbols). 
gigaseals. It could be hypothesised that isolated protoplasts generated walls with a composition different from that of leaf mesophyll cell walls, and that the enzyme cocktail could not permit a complete new digestion.

\section{Discussion}

In vitro tobacco culture is straightforward and tobacco mesophyll cells can be obtained in large amounts so that the efficiency of the protoplast preparation is not limiting. The size of these cells is well adapted to the patch-clamp technique, and we observed that the synthesis of a new cell wall, which makes patch-clamping difficult can appreciably be slowed if cells are kept in the dark during digestion and after transformation. We show that, with the experimental procedure we have developed, a high yield of successful transformation can be routinely obtained and that the time frame for patch-clamp investigations is at least 20 hours wide (Figs. 1 and 4).

Endogenous activity of channels mediating $\mathrm{K}^{+}$inward currents is low in the PEG-transformed tobacco mesophyll protoplasts (Figure 2). This property is favourable for functional characterisation of inward $\mathrm{K}^{+}$channels expressed in this system. Indeed, our data demonstrate the functional expression in these protoplasts of AKT1, a channel so far refractory to expression in classical heterologous expression systems. AKT1 had been previously characterised only in the baculovirus-insect cell system [16] and in yeast cells [34]. Up to now, little has been reported on the functional properties of this channel, one of the first plant Shaker $\mathrm{K}^{+}$channels to be cloned [32], essentially because patch-clamping yeast is difficult and functional studies in $S f 9$ cells require previous purification of recombinant Baculoviruses, a highly time-consuming step, making this system poorly suitable for investigations of structure-function relationships using a number of mutant channels. The present report opens the way towards such investigations, as the expression vectors described here allow easy cDNA cloning and transformation.

A large number of plant genes sharing sequence similarities with animal genes known to encode ion channel subunits have been identified, for instance by in silico analysis of the Arabidopsis genome http://aramem non.botanik.uni-koeln.de/. Most of them are still uncharacterised at the functional level despite attempts to do this in classical animal expression systems. This is the case, for example, of the plant "glutamate receptor" genes [14] and "CNGCs" ones (putative cyclic nucleotide gated cation channels [12]), two gene families having been proposed to encode cation channels [4], and of the "CLC" genes, likely to encode anion channels [15]. In this context, it can be speculated that ion channels of other types than $\mathrm{K}^{+}$ inward rectifiers could be characterised in tobacco meso- phyll protoplasts. Channels mediating outward $\mathrm{K}^{+}$currents (Figure 2C) or channels mediating $\mathrm{Ca}^{2+}\left(\mathrm{Ba}^{2+}\right)$ inward currents and activated by blue light [44] or cAMP [45] have been described in Arabidopsis mesophyll cells and are thus likely to be natively expressed also in tobacco mesophyll cells. Even for such channels, high heterologous expression levels in transformed protoplasts might open the way to their functional analyses.

A drawback in the use of heterologous systems is the fact that the expression context can affect channel functional features, providing a distorted view of the channel function and regulation. For example, the values of the voltage-gating parameters for activation of AKT1 and KAT1 clearly depend on the expression context (Table 1). Regarding KAT1, compared to the value obtained for the native hyperpolarisation-activated $\mathrm{K}^{+}$channels of Arabidopsis guard cells [46], the closest value is the one obtained in the present work (Table 1). Assuming that KAT1 channels do underlie the native Arabidopsis guard cell currents, this suggests that tobacco mesophyll protoplasts represent a more realistic expression context for plant ion channels than classically used animal cells.

Amongst the regulation mechanisms that could be studied using the tobacco mesophyll protoplast system are the events that enable channel targeting to the cell membrane and/or post translational modifications such as (de)phosphorylation. Concerning the former mechanisms, it is worth noting that KAT1 displayed the same subcellular localisation profile when expressed in tobacco mesophyll protoplasts as when expressed in Vicia faba guard cells [21].

Indeed, although peripheral localisation of (at least some) KAT1 channels is assessed by the exogenous currents recorded in protoplasts transformed by KAT1-carrying pFunct+Tag vectors (Figure 3B-D), KAT1::GFP is hardly seen at the membrane (Figure $3 \mathrm{~F}$ ) but rather appears, both in tobacco mesophyll protoplasts and Vicia faba guard cells, as mainly localised in punctate structures (Figure $3 \mathrm{~F}$ ), assumed to belong to the endocytosis pathway (Figure 3F, right photograph; [21]). Interestingly in AKT1::GFP-expressing protoplasts, the fluorescence was not seen in such punctate structures, but appeared as evenly distributed in the plasma membrane (Figure 3E). This indicates that KAT1 and AKT1 channels do not undergo the same regulation concerning their targeting to and/or withdrawal from the cell membrane. Thus, it can be proposed that regulation of $\mathrm{K}^{+}$Shaker channel activity involves specific control of the turn-over of the different Shaker subunits in the cell membrane.

A current challenge in ion channel research is the identification of regulatory proteins and the characterisation of 
the interacting networks they belong to. Progress in this field could be achieved by co-transformation of candidate partners in heterologous systems [47]. The possibility of obtaining co-expression of two distinct polypeptides located on two different plasmids is, therefore, a key feature of an appropriate heterologous expression system. This point had already been checked by immunostaining the nitrocellulose-transferred proteome from protoplasts expressing two different peptides [28]. Here, it has been assessed in situ within living cells and we conclude that PEG-mediated transformation of tobacco mesophyll protoplasts with a mixture of two vectors can be used to study the interaction of two polypeptides. These could be different channel subunits, or a channel subunit and a regulating partner, or any couple of putative interacting polypeptides. Depending on the vectors used, one could study the effect of the interaction on the cellular localisation or on the function of the polypeptides of interest.

\section{Conclusion}

In conclusion, we show that transient expression in tobacco mesophyll protoplasts can provide a way to characterise plant ion channels, by studying for instance their subcellular localisation, functional properties, structurefunction relationships, interacting partners and regulation, very likely in a more realistic context than the classically used animal systems. Clearly, the system is well adapted to characterisation of inward $\mathrm{K}^{+}$channels, and it can be expected to be usable also for the characterisation of other types of ion channels, such as poorly selective cation channels $[48,49]$ or anion channels [15]. Furthermore, adaptation of the procedure to protoplasts prepared from Arabidopsis tissues, using plants of different genotypes, could provide even more straightforward routes to such analyses.

\section{Methods \\ Plant material}

Nicotiana tabacum (cv. SR1) plants were grown in vitro in a growth chamber at $22^{\circ} \mathrm{C}$ with a 16 -h light/8-h dark regime with a photon flux density of $250 \mu \mathrm{mol} . \mathrm{m}^{-2} . \mathrm{s}^{-1} \mathrm{on}$ $0.8 \%$ agar medium containing MS/2 salts [50], $1 \%$ sucrose and $5 \mathrm{mM}$ MES-KOH $\mathrm{pH}$ 5.5).

\section{Genetic material}

The vectors used for transient expression in tobacco mesophyll protoplasts contained either one expression cassette or two. Each cassette is fitted with the enhanced plant promoter of the plasma membrane $\mathrm{H}^{+}$-ATPase isoform 4 gene (pma4) from Nicotiana plumbaginifolia and the nopaline synthase terminator from Agrobacterium tumefasciens (see text and Figure 1A-C). The modified pTZ-19U (Stratagene, LaJolla, CA, USA) plasmid used for functional expression of Shaker channel cDNA in tobacco protoplasts contained two cassettes, allowing to co-express the GFP fluorescent marker protein and the Shaker cDNA sequence ( $p$ Funct+Tag, Figure 1B). XhoI and SmaI restriction sites were used to clone AKT1 and KAT1 CDNA into the expression cassette. The plasmid used for channel targeting contained only one expression cassette allowing the expression of a channel fused in its C-terminal part to the GFP protein ( $p$ Loc, Figure 1A). BglII restriction site and KpnI or BamHI sites were used to clone upstream the GFP, the AKT1 cDNA deprived of its STOP codon by PCR. Supplemental information on the vectors and on the cloning procedure used in this study is available as Additional file 1.

\section{Tobacco leaf mesophyll protoplast isolation}

A previously described protocol [27] was adapted for obtaining purified leaf mesophyll protoplasts.

Five $\mathrm{cm}$ long tobacco leaves from 3- to 4-week-old plants grown in vitro were harvested under sterile conditions and their lower face was abrased with sandpaper $n^{\circ} 1200$. The leaves were then laid in Petri dishes containing $10 \mathrm{ml}$ of the sterilised digestion EF medium (0.125\% macerozyme R-10 (Yakult Pharmaceutical; Onozuka, Japan), 0.2\% cellulase R-10 (Yakult Pharmaceutical; Onozuka, Japan), 5 $\mathrm{mM} \mathrm{CaCl} 2,0.5 \mathrm{M}$ sucrose, $0.1 \% \mathrm{BSA}, 2.5 \mathrm{MES}-\mathrm{HCl}, \mathrm{pH}$ 5.2) for $19 \mathrm{~h}$ in the dark at $25^{\circ} \mathrm{C}$. After digestion, undigested pieces of leaves were removed and $4 \mathrm{ml}$ of floating MLO6 medium were added $\left(15 \mathrm{mM} \mathrm{CaCl}_{2}, 600 \mathrm{mM}\right.$ sucrose, $7.5 \mathrm{mM}$ MES-KOH pH 6.0). The protoplast suspension was then filtered through a $100 \mu \mathrm{m}$ nylon filter and centrifuged at $110 \mathrm{~g}$ for $7 \mathrm{~min}$ in a swinging rotor. The protoplasts localised in the floating band were harvested and diluted with 4 volumes of autoclaved washing W5 medium $\left(154 \mathrm{mM} \mathrm{NaCl}, 125 \mathrm{mM} \mathrm{CaCl}_{2}, 5 \mathrm{mM} \mathrm{KCl}, 5\right.$ $\mathrm{mM}$ glucose and $1.5 \mathrm{mM}$ MES-KOH, $\mathrm{pH}$ 5.6). The cells were then pelleted ( $110 \mathrm{~g}$ for $7 \mathrm{~min}$ in a swinging rotor) and washed in $40 \mathrm{ml}$ and then in $20 \mathrm{ml}$ of "Mannitol/Mg" solution (15 mM MgCl $2,400 \mathrm{mM}$ mannitol, $5 \mathrm{mM}$ MES$\mathrm{KOH} \mathrm{pH} \mathrm{5.6).} \mathrm{Protoplasts} \mathrm{were} \mathrm{finally} \mathrm{resuspended} \mathrm{in}$ Mannitol/Mg solution at a concentration of $10^{6} \mathrm{cells} / \mathrm{ml}$.

\section{Protoplast transformation}

In an Eppendorf tube, $150 \mu \mathrm{l}$ of the concentrated protoplasts and $150 \mu \mathrm{l}$ of PEG solution (25\% w/v PEG 6000, $0.45 \mathrm{M}$ mannitol, $\left.0.1 \mathrm{M} \mathrm{Ca}\left(\mathrm{NO}_{3}\right)_{2}, \mathrm{pH} 9.0\right)$ were added to $5 \mu \mathrm{g}$ of plasmidic DNA from the construction to be tested and incubated at room temperature for $30 \mathrm{~min}$. The sample was then diluted with $8 \mathrm{ml}$ of $\mathrm{K} 3 \mathrm{M}$ medium supplemented with $0.45 \mathrm{M}$ glucose [25] and pelleted in a swinging rotor $(7 \mathrm{~min}$ at $110 \mathrm{~g})$. The protoplasts were finally suspended in $3 \mathrm{ml}$ of $\mathrm{K} 3 \mathrm{M}$ and incubated for 12 to 38 hours at $19^{\circ} \mathrm{C}$ in the dark before analysis. 


\section{Subcellular localisation of channels fused to the GFP and detection of transformed protoplasts for electrophysiological measurements}

Subcellular localisation of the channels fused to the GFP and of FM4-64 labelling in tobacco protoplasts was performed with a Zeiss confocal microscope (LSM510 AX70 Zeiss, Göttingen, Germany). For catching the GFP fluorescence, an excitation wavelength of $488 \mathrm{~nm}$ and a detection one between 500 and $530 \mathrm{~nm}$ were used. For catching the FM4-64 fluorescence, in KAT1::GFP expressing protoplasts, an excitation wavelength of $515 \mathrm{~nm}$ and a detection one above $640 \mathrm{~nm}$ were used, with a laser intensity at 60\%. Different settings for FM4-64 detection were used in AKT1::GFP expressing protoplasts: excitation at $543 \mathrm{~nm}$, detection above $585 \mathrm{~nm}$ and laser intensity at 15\% (much lower chloroplast autofluorescence was catched with such settings, see Figure 3E). Images were treated with LSM510 sofware (Zeiss). Plasma membrane FM4-64 labelling was performed by incubating the protoplasts on ice $10 \mathrm{~min}$ in the culture medium supplemented with $50 \mu \mathrm{M}$ FM4-64. For endocytic vesicle labelling, the incubation in $50 \mu \mathrm{M}$ FM4-64 was prolonged up to $40 \mathrm{~min}$ and performed at room temperature. In order to measure currents only on transformed protoplasts, an epifluorescent microscope (IX 70, Olmpus, Hamburg, Germany) allowing GFP detection was combined with a patch-clamp set-up. Transformed cells were selected for patch-clamp analysis according to their GFP expression. GFP signal was detected between $489 \mathrm{~nm}$ and $508 \mathrm{~nm}$ using a emission filter (piston-GFP, Olympus) upon excitation at a wavelength of $488 \mathrm{~nm}$ emitted by a monochromator (Optoscan C80x, Cairn Research Ltd, UK). Images were acquired with a CCD camera (CoolSNAP HQ, Roper Scientific, USA) and treated with MetaFluor software (Universal Imaging Corporation, USA).

\section{Wall detection}

To measure the kinetics of wall synthesis, the calcofluor white marquer (Fluorescent brightener 28, Sigma) was solubilised in $0.25 \mathrm{M}$ Tris solution at the $0.005 \% \mathrm{w} . \mathrm{v}^{-1}$ concentration. The calcofluor was excited with a 360-370 $\mathrm{nm}$ wavelenght and detected at above $420 \mathrm{~nm}$ with a high-pass emission filter (U-MNU2, Olympus) on an epifluorescent microscope (BX61, Olympus).

\section{Electrophysiological recording}

Patch-clamp pipettes were pulled (P97, Sutter Instruments, Novato, CA) from borosilicate capillaries (Kimax51 , Kimble). Seals with resistances higher than $1 \mathrm{G} \Omega$ were used for electrophysiological analyses. Whole-cell recordings were obtained using an Axopatch 200A amplifier (Axon Instruments, Foster City, CA). pCLAMP 8 software (Axon Instruments) was used for voltage pulse stimulation, on-line data acquisition and data analysis. The volt- age pulse protocols have been included in the figure legends.

\section{Electrophysiological solutions}

For potassium current recordings, the pipette solution that equilibrates with the cytosol of mesophyll protoplasts contained $1 \mathrm{mM} \mathrm{CaCl}_{2}, 5 \mathrm{mM}$ EGTA, $2 \mathrm{mM} \mathrm{MgCl}_{2}$, 100 mM K-glutamate, 2 mM MgATP, 10 mM Hepes$\mathrm{NaOH}, \mathrm{pH} 7.5$, osmolarity adjusted to $520 \mathrm{mOsM}$ with Dmannitol. Mesophyll protoplasts were extracellulary perfused with a solution containing $10 \mathrm{mM} \mathrm{CaCl}_{2}, 2 \mathrm{mM}$ $\mathrm{MgCl}_{2}, 50 \mathrm{mM}$ K-glutamate, $10 \mathrm{mM} \mathrm{MES-HCl,} \mathrm{pH} \mathrm{5.5,}$ osmolarity adjusted to $500 \mathrm{mOsM}$ with D-mannitol. In these conditions, pipette resistances were about $12 \mathrm{M} \Omega$.

The pipette solution used for chloride current recordings was composed of $30 \mathrm{mM} \mathrm{CsCl}, 2 \mathrm{mM} \mathrm{MgCl}_{2}, 1 \mathrm{mM} \mathrm{CaCl}_{2}$ (free $\mathrm{Ca}^{2+}$ about $50 \mathrm{nM}$ ), 5 mM EGTA, 2 mM MgATP, 10 $\mathrm{mM}$ Hepes/Tris ( $\mathrm{pH} 7.2$ ) and $410 \mathrm{mM}$ D-mannitol. The bath solution contained $50 \mathrm{mM} \mathrm{CsCl}, 15 \mathrm{mM} \mathrm{CaCl}_{2}, 2$ $\mathrm{mM} \mathrm{MgCl}{ }_{2}, 10 \mathrm{mM}$ Mes/Tris (pH 5.7) and $345 \mathrm{mM}$ Dmannitol. In these conditions, patch pipettes had resistances of about $15 \mathrm{M} \Omega$.

\section{Competing interests}

The author(s) declare that they have no competing interests.

\section{Authors' contributions}

EH carried out the patch-clamp recordings, except those regarding endogenous anion currents, participated in the protoplast transformation and drafted the manuscript. GD designed and obtained the expression vectors used in this work, managed the protoplast transformation, performed the confocal microscopy and drafted the manuscript. AAV performed the patch-clamp recordings of the endogenous anion currents and cell wall detection experiments. AC participated in the protoplast transformation and obtainig of expression vectors. HS participated in the design and the coordination of the study and helped to draft the manuscript. JBT participated in the design and the coordination of the study and managed the writing of the manuscript.

\section{Additional material}

\section{Additional File 1}

Supplemental information on the vectors and on the cloning procedure used in this study. This 2 page file (pdf format) displays 2 figures (and legends) showing (i) a schematic representation of the vectors used in this work and (ii) the procedure for cloning cDNAs in these vectors. Click here for file

[http://www.biomedcentral.com/content/supplementary/17464811-1-14-S1.pdf] 


\section{Acknowledgements}

Eric Hosy was granted by Région Languedoc-Roussillon and INRA. Geoffrey Duby was supported by European Union (Marie Curie fellowship). Région Languedoc-Roussillon funded the acquisition of the experimental set-up for coupled patch-clamp and GFP imaging ("arrêté distributif $n^{\circ} 0061$ 67"). This work was in part supported by the "Programme inter-organismes (CEA-CNRS-INRA-INSERM) de Toxicologie Nucléaire". Preliminary attempts of KATI functional expression were performed with a KATI ::GFP construct kindly provided by Dr Ulrike Homann, Technical University of Darmstadt, Germany. We warmly thank Dr Françoise Bex (Laboratory of Microbiology, University of Brussels, Belgium) for her help in confocal microscopy. We are indebted to $\mathrm{Dr}$ Isabel A. Lefèvre for helpful discussions and comments on the manuscript.

\section{References}

I. Noda M, Shimizu S, Tanabe T, Takai T, Kayano T, lkeda T, Takahashi $\mathrm{H}$, Nakayama H, Kanaoka Y, Minamino N, et al.: Primary structure of Electrophorus electricus sodium channel deduced from cDNA sequence. Nature 1984, 3 I 2: 121-127.

2. Sumikawa K, Houghton M, Emtage JS, Richards BM, Barnard EA: Active multi-subunit $A C h$ receptor assembled by translation of heterologous mRNA in Xenopus oocytes. Nature 1981, 292:862-864.

3. Zimmermann S, Sentenac H: Plant ion channels : from molecular structures to physiological functions. Curr Opin Plant Biol 1999, 2:477-482

4. Véry A-A, Sentenac $\mathrm{H}$ : Molecular mechanisms and regulation of $\mathbf{K}^{+}$transport in higher plants. Annu Rev Plant Biol 2003, 54:575-603.

5. Stühmer W: Electrophysiologic recordings from Xenopus oocytes. Methods Enzymol 1998, 293:280-300.

6. Luckow VA, Summers MD: Signals important for high-level expression of foreign genes in Autographa californica nuclear polyhedrosis virus expression vectors. Virology 1988, 167:56-7|.

7. Rychkov GY, Pusch M, Astill DS, Roberts ML, Jentsch TJ, Bretag AH: Concentration and $\mathrm{pH}$ dependence of skeletal muscle chloride channel CIC-I. Journal of Physiology 1996, 497:423-435.

8. Ukomadu C, Zhou J, Sigworth FJ, Agnew WS: mul $\mathbf{N a}^{+}$channels expressed transiently in human embryonic kidney cells: biochemical and biophysical properties. Neuron 1992, 8:663-676.

9. Mellon P, Parker V, Gluzman Y, Maniatis T: Identification of DNA sequences required for transcription of the human alpha Iglobin gene in a new SV40 host-vector system. Cell I98I, 27:279-288.

10. Gu Y, Franco A Jr, Gardner PD, Lansman JB, Forsayeth JR, Hall ZW: Properties of embryonic and adult muscle acetylcholine receptors transiently expressed in COS cells. Neuron 1990, 5:147-157.

II. Dreyer I, Antunes S, Hoshi T, Müller-Röber B, Palme K, Pongs O, Reintanz G, Hedrich R: Plant $K^{+}$channel $\alpha$-subunits assemble indiscriminately. Biophys J 1997, 72:2143-2150.

12. Talke IN, Blaudez D, Maathuis F], Sanders D: CNGCs: prime targets of plant cyclic nucleotide signalling? Trends Plant Sci 2003, 8:286-293.

13. Lacombe B, Becker D, Hedrich R, DeSalle R, Hollmann M, Kwak JM, Schroeder Jl, Le Novere N, Nam HG, Spalding EP, et al.: The identity of plant glutamate receptors. Science 200I, 292: | 486-| 487.

14. Bouche N, Lacombe B, Fromm H: GABA signaling: a conserved and ubiquitous mechanism. Trends Cell Biol 2003, I3:607-6I0.

15. Barbier-Brygoo H, Vinauger M, Colcombet J, Ephritikhine G, Frachisse J, Maurel C: Anion channels in higher plants: functional characterization, molecular structure and physiological role. Biochimica Biophysica Acta 2000, | 465:199-2I8.

16. Gaymard F, Cerutti M, Horeau C, Lemaillet G, Urbach S, Ravallec M, Devauchelle G, Sentenac H, Thibaud J-B: The baculovirus/insect cell system as an alternative to Xenopus oocytes. First characterization of the AKTI $\mathrm{K}^{+}$channel from Arabidopsis thaliana. Biol Chem 1996, 271:22863-22870.

17. Bei Q, Luan S: Functional expression and characterization of a plant $\mathrm{K}^{+}$channel in a plant cell model. Plant J 1998, 13:857-865.
18. Horsch RB, Fry JE, Hoffmann NL, Eichholrz D, Rogers SG, Fraley RT: A simple and general method for transferring genes into plants. Science 1985, 227:1229-I23I.

19. Sheen J, Hwang S, Niwa Y, Kobayashi H, Galbraith DW: Green-fluorescent protein as a new vital marker in plant cells. Plant J 1995, 8:777-784.

20. Plautz JD, Day RN, Dailey GM, Welsh SB, Hall JC, Halpain S, Kay SA: Green fluorescent protein and its derivatives as versatile markers for gene expression in living Drosophila melanogaster, plant and mammalian cells. Gene 1996, 173:83-87.

21. Hurst AC, Meckel T, Tayefeh S, Thiel G, Homann U: Trafficking of the plant potassium inward rectifier KATI in guard cell protoplasts of Vicia faba. Plant J 2004, 37:39I-397.

22. Gustafson CE, Levine S, Katsura T, McLaughlin M, Aleixo MD, Tamarappoo BK, Verkman AS, Brown D: Vasopressin regulated trafficking of a green fluorescent protein-aquaporin 2 chimera in LLC-PK I cells. Histochem Cell Biol 1998, I 1 0:377-386.

23. Duby G, Oufattole M, Boutry M: Hydrophobic residues within the predicted $\mathrm{N}$-terminal amphiphilic alpha-helix of a plant mitochondrial targeting presequence play a major role in in vivo import. Plant J 200I, 27:539-549.

24. Zhao R, Moriau L, Boutry M: Expression analysis of the plasma membrane $\mathrm{H}^{+}$-ATPase pma4 transcription promoter from Nicotiana plumbaginifolia activated by the CaMV 355 promoter enhancer. Plant Sci 1999, 149: 157-165.

25. Negrutiu I, Hinnisdaels S, Cammaerts D, Cherdshewasart W, GhartiChhetri G, Jacobs M: Plant protoplasts as genetic tool: selectable markers for developmental studies. International Journal of Developmental Biology 1992, 36:73-84.

26. Maathuis FJM, May ST, Graham NS, Bowen HC, Jelitto TC, Trimmer P, Bennett MJ, Sanders D, White PJ: Cell marking in Arabidopsis thaliana and its application to patch-clamp studies. Plant J 1998, 15:843-85I.

27. Lukaszewicz M, Jerouville B, Boutry M: Signs of translational regulation within the transcript leader of a plant plasma membrane $\mathrm{H}^{+}$-ATPase gene. Plant $J$ 1998, I 4:413-423.

28. Locatelli F, Vannini C, Magnani E, Coraggio I, Bracale M: Efficiency of transient transformation in tobacco protoplasts is independent of plasmid amount. Plant Cell Rep 2003, $21: 865-871$.

29. Ache P, Becker D, Ivashikina N, Dietrich P, Roelfsema MR, Hedrich $R$ : GORK, a delayed outward rectifier expressed in guard cells ofArabidopsis thaliana, is a $\mathrm{K}^{+}$-selective, $\mathrm{K}^{+}$-sensing ion channel. FEBS Lett 2000, 486:93-98.

30. Gaymard F, Pilot G, Lacombe B, Bouchez D, Bruneau D, Boucherez J, Michaux-Ferrière $N$, Thibaud J-B, Sentenac $\mathrm{H}$ : Identification and disruption of a plant shaker-like outward channel involved in $\mathrm{K}^{+}$release into the xylem sap. Cell 1998, 94:647-655.

31. Hosy E, Vavasseur A, Mouline K, Dreyer I, Gaymard F, Porée F, Boucherez J, Lebaudy A, Bouchez D, Véry A-A, et al.: The Arabidopsis outward $\mathrm{K}^{+}$channel GORK is involved in regulation of stomatal movements and plant transpiration. Proc Natl Acad Sci USA 2003, 100:5549-5554.

32. Sentenac H, Bonneaud N, Minet M, Lacroute F, Salmon JM, Gaymard $\mathrm{F}$, Grignon C: Cloning and expression in yeast of plant potassium ion transport system. Science 1992, 256:663-665.

33. Anderson JA, Huprikar SS, Kochian LV, Lucas W], Gaber RF: Functional expression of a probable Arabidopsis thaliana potassium channel in Saccharomyces cerevisiae. Proc Natl Acad Sci USA 1992, 89:3736-3740.

34. Bertl A, Reid JD, Sentenac H, Slayman CL: Functional comparison of plant inward-rectifier channels expressed in yeast. J Exp Bot 1997, 48:405-4|3.

35. Schachtman DP, Schroeder JI, Lucas WJ, Anderson JA, Gaber RF: Expression of an inward-rectifying potassium channel by the Arabidopsis KATI cDNA. Science 1992, 258:1654-I658.

36. Véry A-A, Gaymard F, Bosseux C, Sentenac H, Thibaud J-B: Expression of a cloned plant $\mathrm{K}^{+}$channel in Xenopus oocytes: analysis of macroscopic currents. Plant J 1995, 7:321-332.

37. Su $Y-H$, North H, Grignon C, Thibaud J-B, Sentenac H, Véry A-A: Regulation by external $\mathrm{K}^{+}$in a maize inward Shaker channel targets transport activity in the high concentration range. Plant Cell 2005, I 7:1532-1548.

38. Marten I, Gaymard F, Lemaillet G, Thibaud JB, Sentenac H, Hedrich R: Functional expression of the plant $\mathrm{K}^{+}$channel KATI in insect cells. FEBS Lett 1996, 380:229-232. 
39. Bertl A, Anderson JA, Slayman CL, Gaber RF: Use of Saccharomyces cerevisiae for patch clamp analysis of heterologous membrane proteins: characterization of Katl, an inwardrectifying $\mathrm{K}^{+}$channel from Arabidopsis thaliana, and comparison with endogenous yeast channels and carriers. Proc Natl Acad Sci USA 1995, 92:270I-2705.

40. Reintanz B, Szyroki A, Ivashikina N, Ache P, Godde M, Becker D, Palme K, Hedrich R: AtKCl, a silent Arabidopsis potassium channel alpha -subunit modulates root hair $\mathrm{K}^{+}$influx. Proc Natl Acad Sci USA 2002, 99:4079-4084.

41. Dreyer I, Horeau C, Lemaillet G, Zimmermann S, Bush DR, Rodriguez-Navarro A, Schachtman DP, Spalding EP, Sentenac H, Gaber RF: Identification and characterization of plant transporters using heterologous expression systems. J Exp Bot 1999, 50:1073-1087.

42. Haupt S, Cowan GH, Ziegler A, Roberts AG, Oparka KJ, Torrance L: Two plant-viral movement proteins traffic in the endocytic recycling pathway. Plant Cell 2005, I7:164-I8I.

43. Ueda T, Yamaguchi M, Uchimiya H, Nakano A: Ara6, a plantunique novel type Rab GTPase, functions in the endocytic pathway of Arabidopsis thaliana. EMBO J 200I, 20:4730-474I.

44. Stoelzle S, Kagawa T, Wada M, Hedrich R, Dietrich P: Blue light activates calcium-permeable channels in Arabidopsis mesophyll cells via the phototropin signaling pathway. Proc Natl Acad Sci USA 2003, 100: |456-|46I.

45. Lemtiri-Chlieh F, Berkowitz GA: Cyclic adenosine monophosphate regulates calcium channels in the plasma membrane of Arabidopsis leaf guard and mesophyll cells. J Biol Chem 2004, 279:35306-35312

46. Roelfsema MRG, Prins HBA: Ion channels in guard cells of Arabidopsis thaliana (L.) Heynh. Planta 1997, 202:18-27.

47. Chérel I, Michard E, Platet N, Mouline K, Alcon C, Sentenac H, Thibaud J-B: Physical and functional interaction of the Arabidopsis $\mathrm{K}^{+}$channel AKT2 and phosphatase AtPP2CA. Plant Cell 2002, I 4: I |33-I | 46 .

48. Demidchik V, Davenport RJ, Tester M: Nonselective cation channels in plants. Annu Rev Plant Biol 2002, 53:67-107.

49. Véry A-A, Sentenac $H$ : Cation channels in the Arabidopsis plasma membrane. Trends Plant Sci 2002, 7:168-175.

50. Murashige T, Skoog F: A revised medium for rapid growth and bio-assays with tobacco tissues culture. Physiol Plant 1962 , 15:473-497.

Publish with Bio Med Central and every scientist can read your work free of charge

"BioMed Central will be the most significant development for disseminating the results of biomedical research in our lifetime. "

Sir Paul Nurse, Cancer Research UK

Your research papers will be:

- available free of charge to the entire biomedical community

- peer reviewed and published immediately upon acceptance

- cited in PubMed and archived on PubMed Central

- yours - you keep the copyright

Submit your manuscript here:

http://www.biomedcentral.com/info/publishing_adv.asp
BioMedcentral 